\title{
El Niño-Southern Oscillation effect on a fire regime in northeastern Mexico has changed over time
}

\author{
Larissa L. Yocom, ${ }^{1,6}$ Peter Z. Fulé, ${ }^{1}$ Peter M. Brown, ${ }^{2}$ Julián Cerano, ${ }^{3}$ José Villanueva-Díaz, ${ }^{3}$ \\ Donald A. Falk, ${ }^{4}$ and Eladio Cornejo-Oviedo ${ }^{5}$ \\ ${ }^{1}$ School of Forestry and Ecological Restoration Institute, Northern Arizona University, P.O. Box 15018, \\ Flagstaff, Arizona 86011-5018 USA \\ ${ }^{2}$ Rocky Mountain Tree-Ring Research, Incorporated, 2901 Moore Lane, Ft. Collins, Colorado 80526 USA \\ ${ }^{3}$ Instituto Nacional de Investigaciones Forestales, Agrícolas, y Pecuarias, Centro Nacional de Investigación Disciplinaria en Relación \\ Agua, Suelo, Planta, Atmósfera, Gomez Palacio, Durango 35140 Mexico \\ ${ }^{4}$ School of Natural Resources and Laboratory of Tree-Ring Research, Biological Sciences East, University of Arizona, \\ Tucson, Arizona 85721 USA \\ ${ }^{5}$ Departamento Forestal, Universidad Autónoma Agraria “Antonio Narro," Saltillo, Coahuila, Mexico
}

\begin{abstract}
The El Niño Southern Oscillation (ENSO) is a climate-forcing mechanism that has been shown to affect precipitation and the occurrence of wildfires in many parts of the world. In the southern United States and northern Mexico, warm events (El Niño) are associated with moist winter conditions and fewer fires, while cool events (La Niña) tend to favor dry winters and more fires. We tested this relationship in a region of northeastern Mexico by characterizing the historical fire regime and climatic influences. Fire regimes were reconstructed from fire-scar samples collected from 100 trees in three high-elevation sites on Peña Nevada in southern Nuevo León. The sites were $\sim 25$ ha each, and the site centers were $\sim 1 \mathrm{~km}$ apart. The earliest recorded fire occurred in 1521 and the time period we used for analysis was 1645-1929. The sites were characterized by frequent surface fires before the 1920s. In the three sites, mean fire intervals ranged from 8.6 to 9.6 years (all fires) and 11.9 to 18.6 years (fires that scarred $\geq 25 \%$ of recording trees). The per-tree mean fire return interval was 17 years, and all three sites burned in the same year seven times between 1774 and 1929. After 1929, fires were nearly eliminated in all sites, likely due to human causes. We found a temporal change in the association between ENSO events and fires; before the 1830s La Niña events were significantly associated with fire years, while after the 1830s this association was not significant. In 1998, when the most severe El Niño event of the past century occurred, the three sites experienced severe, stand-replacing fires that killed many trees that had survived multiple surface fires in the past. Prior to the 1830s, fires tended to occur during dry La Niña years, but since then both La Niña and El Niño have been associated with dry years in this region, especially during the last three decades. This result suggests that ENSO effects have changed over time in this location and that phases of ENSO are not consistent indicators of precipitation, fire occurrence, or fire behavior in this area of northeastern Mexico.
\end{abstract}

Key words: El Niño Southern Oscillation; fire history; fire scars; Peña Nevada, southern Nuevo León, Mexico; Pinus hartwegii.

\section{INTRODUCTION}

In western North America, the El Niño Southern Oscillation (ENSO) is a climate-forcing mechanism that has been shown to affect precipitation and the occurrence of fires. Linkages between ENSO and the occurrence of forest fires have been recognized at scales ranging from local and regional (Swetnam 1990, Heyerdahl and Alvarado 2003, Brown and Wu 2005, Fulé et al. 2005, Skinner et al. 2008) to subcontinental and intercontinental (Kitzberger et al. 2001, 2007). La Niña winters (ENSO cool phase) in northwestern

Manuscript received 12 May 2009; revised 11 September 2009; accepted 22 September 2009; final version received 19 October 2009. Corresponding Editor: D. P. C. Peters.

${ }^{6}$ E-mail: larissa.yocom@gmail.com
Mexico are typically hot and dry, as they are in the American Southwest, and fires are more likely to burn during these years (Swetnam and Betancourt 1990, Heyerdahl and Alvarado 2003, Fulé et al. 2005, Kitzberger et al. 2007, Skinner et al. 2008). In southern Mexico, however, El Niño winters (ENSO warm phase) are dry and fire-prone (Magaña et al. 2003, RománCuesta et al. 2004, Seager et al. 2009).

The extreme El Niño event of 1998 was associated with a widespread drought and severe forest fires in Mexico. It was an unprecedented year for Mexico in terms of number of fires, area and biomass burned, smoke released, cost of suppression, and firefighter lives lost (Rodríguez-Trejo and Pyne 1999, Duncan et al. 2003). Most of the fires were located in the southern part of the country (Rodríguez-Trejo and Pyne 1999), where 
El Niño typically induces drought. However, severe fires also burned farther north in Mexico, in the Sierra Madre Oriental.

The Sierra Madre Oriental, in eastern Mexico, is located on or near the dipole where ENSO events change effects; it is situated between areas where La Niña is associated with dry conditions (northwestern Mexico), and areas where El Niño is associated with dry conditions (southern Mexico) (Caso et al. 2007, Seager et al. 2009). Because of its geographical location on or near the ENSO dipole, it is unknown whether warm or cool phases of the oscillation are more likely to be associated with fire occurrence in this area. Severe fires burned in the Sierra Madre Oriental during the $1998 \mathrm{El}$ Niño event, but the 1998 El Niño was extremely strong and therefore may have had atypical effects on fires in this region.

The types of fire behavior that occur in high-elevation forests of the Sierra Madre Oriental are also unknown. Severe fires in 1998 devastated many stands of trees, but this level of severity may have been an anomaly compared to the historical fire regime. Pinus hartwegii (Lindl.), a dominant tree species at high elevation in the Sierra Madre Oriental and elsewhere in Mexico and Guatemala (Farjon and Styles 1997), has several adaptations to fire, including thick bark and the ability to resprout after fire (Rodríguez-Trejo and Fulé 2003). While thick bark is usually considered an adaptation to surface fire, sprouting sometimes occurs in trees adapted to intense crown fire (Keeley and Zedler 1998).

Although there have been several studies of $P$. hartwegii fire ecology, this is the first fire history study in a $P$. hartwegii forest and the first long-term fire history study in the Sierra Madre Oriental. González et al. (2007) reconstructed fire history of a pine-oak forest (P. teocote, P. pseudostrobus) in the northern Sierra Madre Oriental, but their tree-ring record reached back only to 1868 . Fire history studies in northwestern Mexico, in the Sierra Madre Occidental (Fulé and Covington 1994, Heyerdahl and Alvarado 2003), and in the Sierra San Pedro Mártir (Stephens et al. 2003) indicate that fires occurred frequently in the past and that fire regimes continued uninterrupted well into the 20th century. The Sierra Madre Oriental contains high biodiversity, including 59 endemic plant species that inhabit $<6 \mathrm{~km}^{2}$ each (McDonald 1993). At least $35 \%$ of timberline plant species in the range are endemic to the Sierra Madre Oriental (McDonald 1990). Peña Nevada, the location of our study, has 10 plant species endemic to the peak alone (McDonald 1993). We selected Peña Nevada to quantify long-term fire regimes because of its critical location in a transition zone of ENSO effects as well as the high conservation value of this rare ecosystem.

The objectives of this study were (1) to characterize the historical fire regime in the $P$. hartwegii forests of Peña Nevada, including fire frequency, type, size, season, and synchrony, and (2) to determine whether fire years were associated with ENSO. Specific questions included: What were the characteristics of the fire regime? Was the fire regime interrupted in the 20th century? What are the effects of ENSO on fires in this region of Mexico? Were the fires in the 1998 El Niño an anomaly?

\section{Study Area}

Peña Nevada, at $3540 \mathrm{~m}$ elevation, is located in the Sierra Madre Oriental in the state of Nuevo León, Mexico (Fig. 1). We focused on Peña Nevada (also called El Picacho San Onofre) primarily for biogeographical reasons: it is the southernmost peak in the high, consolidated part of the Sierra Madre Oriental that runs from just south of Monterrey to southern Nuevo León and southwestern Tamaulipas, and it is located between areas where ENSO events have opposite effects. We chose specific sites on the mountain because of their history of relatively light anthropogenic disturbance prior to the 1998 fire, the presence of $P$. hartwegii forests, which were least anthropogenically disturbed at the highest elevations, and the presence of old trees or old remnant wood. In addition, the sites were spaced along a broad ridgeline, which would allow them to capture evidence of fires spreading up either side of the mountain.

The study area is located at $\sim 3200 \mathrm{~m}$ above sea level. Climate data from lower-elevation weather stations to the southeast and southwest of Peña Nevada (Uvalles, $1565 \mathrm{~m}$ and San Antonio Peña Nevada, $1680 \mathrm{~m}$ ) averaged annual precipitation of $335 \mathrm{~mm}$, with peaks in late spring and late summer (IMTA 2007). The precipitation at sites $>2800 \mathrm{~m}$ in the Sierra Madre Oriental is estimated to be $450-500 \mathrm{~mm}$ annually (J. Villanueva-Diaz, unpublished data), but the percentage of precipitation that falls as snow is unknown. Average yearly temperature at the two lower-elevation stations is $10.8^{\circ} \mathrm{C}$ (IMTA 2007), but the average yearly temperature at our study sites is certainly lower. The majority of lightning storms in the area occur in the spring (IMTA 2007). Exposed rock in the Sierra Madre Oriental is limestone (Ferrusquía-Villafranca 1993).

The sites we sampled are dominated almost exclusively by $P$. hartwegii. After the severe fire in 1998, some parts of Peña Nevada experienced high tree mortality and were later salvage logged. Because of this, much of the area we sampled was essentially clearcut, with some pockets of intact forest.

In 1984, Andrew McDonald witnessed and took a photo of a recently burned area in a remote area on Peña Nevada, not near our sampling sites (A. McDonald, personal communication). The photo shows that some of the forest burned severely; only charred snags are left in the burned area. It is likely that the severe fire happened in 1983; the needles on the trees at the edge of the burn were orange but had not yet fallen by 1984 . The year 1983 was dry at Peña Nevada, which also lends credence to the 1983 date. 


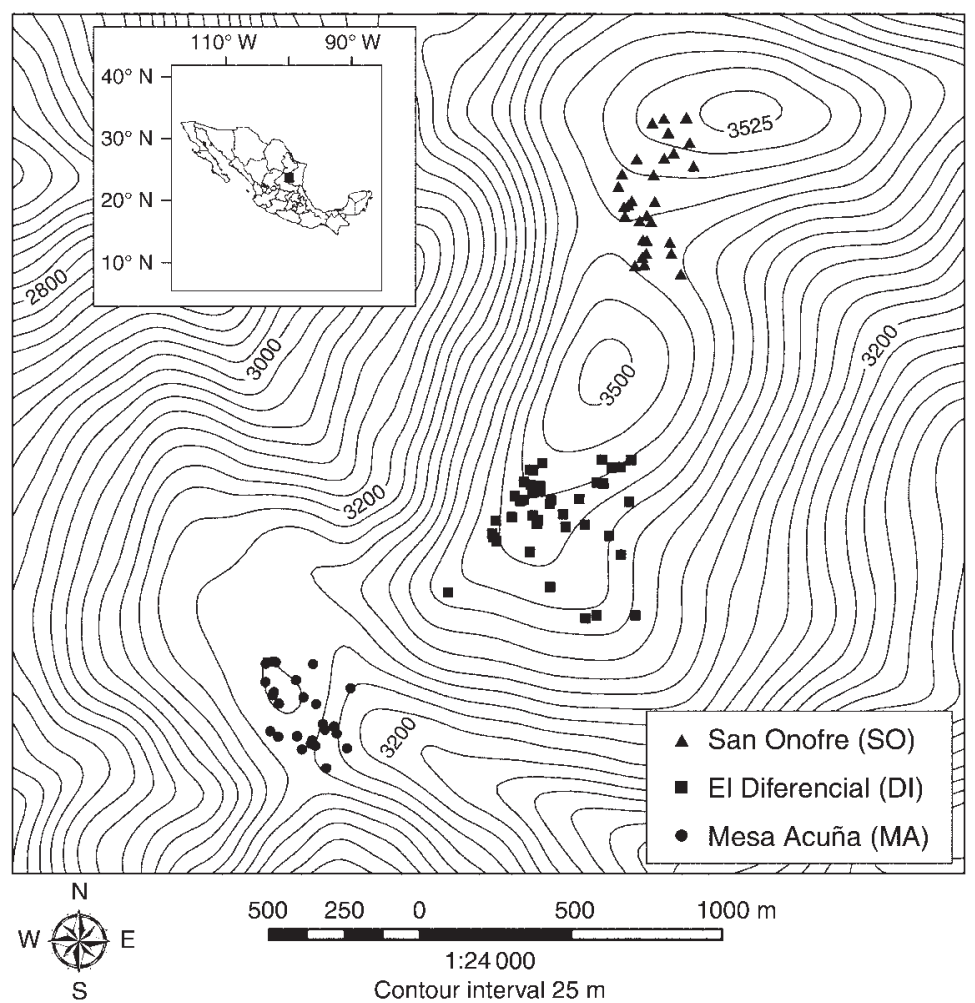

FIG. 1. Map of the three study sites arrayed along the ridge north of Peña Nevada peak, Nuevo León, Mexico.

\section{Methods}

We collected fire-scarred tree samples at Peña Nevada in 2007. We established three sites of $\sim 25$ ha each at San Onofre (SO), El Diferencial (DI), and Mesa Acuña (MA) (Fig. 1). The sites were spaced $\sim 1 \mathrm{~km}$ apart and had comparable elevation and vegetation. All had moderate slopes, situated on top of a broad ridgeline. We systematically searched each site and took firescarred samples that would provide good spatial distribution throughout the site. We chose to sample trees of any species with the largest numbers of wellpreserved fire scars (Van Horne and Fulé 2006), but we also sampled live trees, which often had only one or two scars, to ensure that the fire history extended up to the present. We used chain saws to remove partial cross sections of fire-scarred trees. Data recorded for each sample were tree species and diameter, status (live, stump, snag, or log), slope, aspect, and fire scar height and aspect. We georeferenced each sample to map the spatial distribution of the samples.

In the laboratory, samples were sanded with increasingly finer grits of sandpaper until individual cells were clearly visible under a microscope. We crossdated each sample using a Pseudotsuga menziesii (Mirb.) Franco tree-ring chronology from nearby on Peña Nevada (Villanueva-Diaz et al. 2007). The crossdating of each sample was confirmed by a second dendrochronologist. We measured the ring widths of each sample and checked the crossdating with the COFECHA software program (Holmes 1983).

We identified fire scars to the year of origin by noting the crossdated ring in which the fire injury occurred (Baisan and Swetnam 1990). When possible, fire scars were determined to be located in the early earlywood (EE), middle earlywood (ME), late earlywood (LE), latewood (L), or on the boundary between rings (indicating a dormant [D] season fire). We assigned dormant season fires to the subsequent calendar year because most fires in areas with similar precipitation patterns burn prior to the summer rains. We grouped fires into spring $(\mathrm{D}+\mathrm{EE})$ and summer $(\mathrm{ME}+\mathrm{LE}+\mathrm{L})$ categories for seasonal evaluation.

Fire history statistics were calculated for periods in which there was an adequate tree-ring record. Each site was determined to have an adequate tree-ring record when at least $10 \%$ of total samples in that site were scarred. The same criterion was used when calculating statistics for the three sites combined. In the three sites combined, the period with an adequate tree-ring record was 1645-1929. Each site individually had an adequate tree-ring record from 1641 to 1920 (SO), 1645-1929 (DI), and 1774-1928 (MA).

Fire history statistics were calculated with FHX2 version 3.2 software (Grissino-Mayer 2001). For each site and for all three sites combined, we calculated the composite mean fire interval between all fires and also between more widespread fires that scarred at least $25 \%$ 
of recording trees. Recording trees are trees that have been scarred by fire once; after an initial wound, trees of some species are more likely to scar in subsequent fires (Romme 1980) and therefore are "recording trees." We calculated Weibull median and modal fire intervals, and looked for temporal differences in mean fire interval, seasonality of fires, and fire relationship with precipitation and ENSO between the first portion of the period of analysis (1645-1831) and the second portion (18321929). We split the analysis at $1831 / 1832$ not a priori but because one of our results, a graph of ENSO extremes and precipitation at Peña Nevada, showed an unexpected change in relationship around that time. We also examined the fire history at Peña Nevada for evidence of a hiatus in fire occurrence that would coincide with a late 18th-early 19th centuries gap in fire documented at many sites in the southwestern United States and northwestern Mexico (Swetnam 1990, Kitzberger et al. 2001, Stephens et al. 2003, Brown and Wu 2005, Skinner et al. 2008).

To evaluate climate conditions related to fire occurrence at our study sites, we used superposed epoch analysis (SEA) in FHX2 version 3.2 (Baisan and Swetnam 1990, Swetnam 1993, Grissino-Mayer 2001) to compare independently derived indices of ENSO and precipitation during fire years, for five years prior to fire years, and for two years after fire years. Reconstructions used include a reconstruction of winter ENSO (NINO3, December-February, 1408-1978; Cook 2000), and a local precipitation reconstruction (Villanueva-Diaz et al. 2007). The time series of precipitation had no temporal autocorrelation, but the NINO3 index did. To address the temporal autocorrelation in the NINO3 index, we fit autoregressive integrated moving average models based on lowest Akaike's information criterion and significant but uncorrelated parameter estimates (Brown et al. 2008). We used the white noise residuals in our analyses. To assess statistical significance in the SEA analyses, confidence intervals $(95 \%)$ were calculated using bootstrapped distributions of climate data in 1000 trials. We compared ENSO and precipitation indices with the occurrence of all fires regardless of size, as well as widespread fires that scarred at least $25 \%$ of recording trees in all three sites. We completed these analyses for the entire period with an adequate tree-ring record (1645-1929) and also for the first part of this period alone (1645-1831) and the second part alone (18321929).

We plotted extreme ENSO events on a local precipitation reconstruction based on $P$. menziesii annual rings (Villanueva-Diaz et al. 2007). Extreme winter Southern Oscillation Index (SOI) values were identified between 1699 and 1971 by Stahle and Cleaveland (1993), using tree-ring records from Mexico and the United States. Stahle and Cleaveland used two methods to reconstruct extreme SOI values, regression and classification, and considered the most accurate list of extremes to be a list of years when both methods obtained the same results for extreme winter SOI values. This is the list we used. After 1971, we determined extreme winter SOI values to be December-JanuaryFebruary (DJF) average values (SOI data from NCAR's Climate Analysis Section Data Catalog (available online $)^{7}$ that were $>1.5$ standard deviations from the average DJF values from 1935 to 2006. Using this method, extreme winter SOI values after 1971 were in 1974 and 1976 (La Niña events), and 1983, 1992, and 1998 (El Niño events).

\section{RESULTS}

Fire history

We collected a total of 112 samples: 34 in SO, 48 in DI, and 30 in MA. The majority of samples were taken from stumps and all but one of the samples were from $P$. hartwegii; the exception came from a single $P$. menziesii. We were able to crossdate 100 of the samples $(89 \%)$ and we identified 408 scars in total. We were unable to date 12 samples $(11 \%)$ because of rotten wood, rings that were too tight, or an insufficient number of rings to permit reliable crossdating.

The earliest fire scar identified in our three sites occurred in 1521, and the last fire scars were from 1998, the year that much of the forest in our sites burned severely. Until the late 1920 s, the fire regime at Peña Nevada showed relatively little variability across sites and through time (Fig. 2). The mean fire interval for all fires was within one year's difference between sites (SO, 9.3 years; DI, 8.6 years; MA, 9.6 years; Table 1$)$. The mean fire interval for more widespread fires (those that burned $\geq 25 \%$ of the trees) was longer, and varied from 11.9 years in MA to 18.6 years in SO (Table 1). The Weibull distribution, which has been used in describing fire regimes because it is flexible, able to fit skewed data sets, and provides a standard way to compare fire regimes across ecological gradients (Grissino-Mayer 1999), fit our data well. Weibull median probability interval values were similar to mean fire interval values (Table 1). The mean fire interval for individual trees was 17 years. There were no statistically significant temporal differences in mean fire interval or percentage of samples scarred between 1645-1831 and 1832-1929.

Two of the three sites (SO and DI) have a continuous record starting in the early 1500s and large numbers of samples starting in the 1600 s. Site MA is the only site that does not have a continuous record that precedes the early 1700s. Two samples were found in MA that span the mid-1500s to the mid-1600s, but there is a gap in sample coverage between the mid-1600s and the early 1700s. MA did have one pulse of regeneration in the early 1700s; seven out of nine pith dates in that site were from between 1726 and 1742. Sites SO and DI had 18 samples that contained pith; pith dates were scattered

\footnotetext{
${ }^{7}\langle$ http://www.cgd.ucar.edu/cas/catalog/climind/ $\rangle$
} 


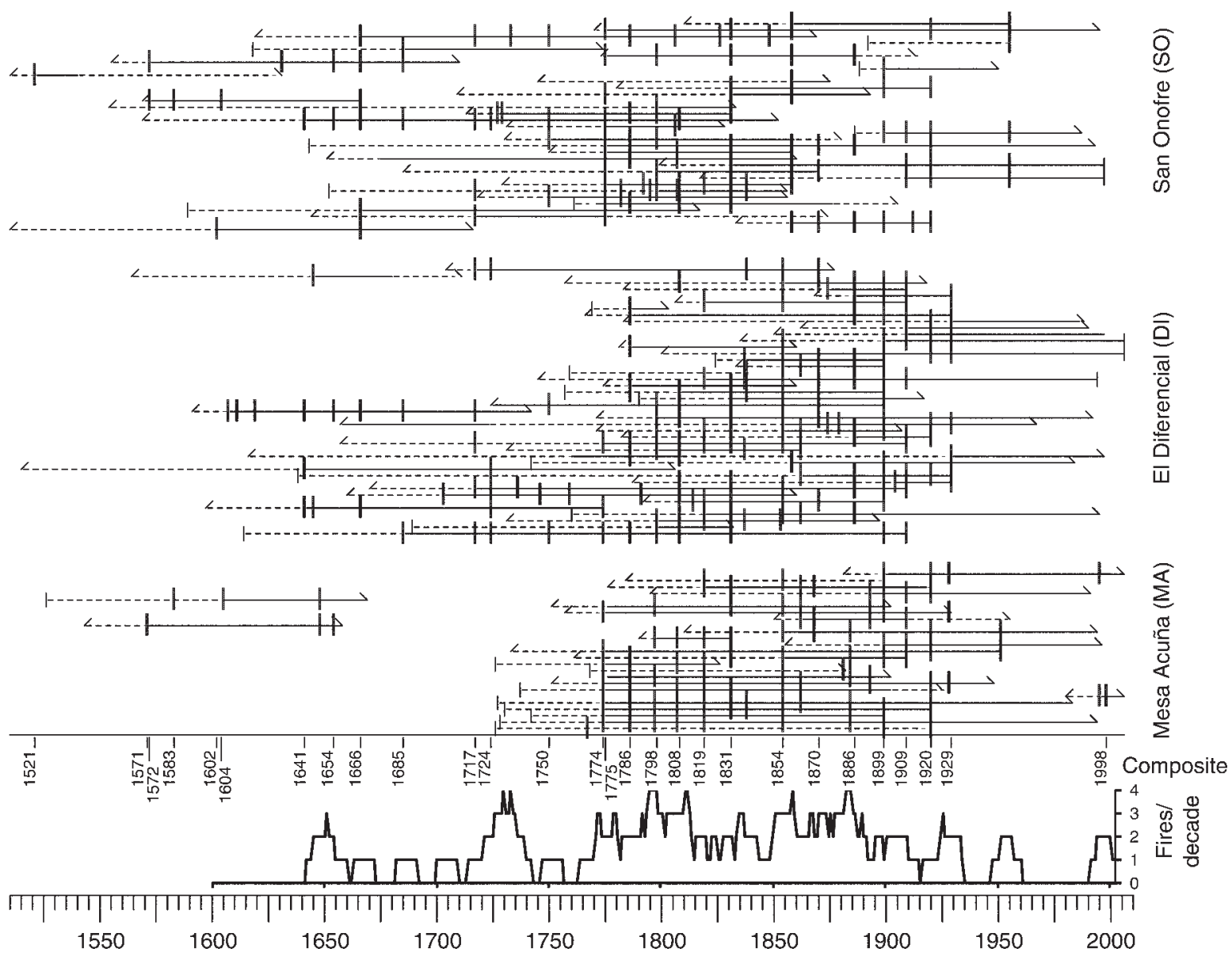

FIG. 2. Fire history chart of Peña Nevada for the years 1510-2006. Horizontal lines represent samples, and vertical lines represent fire scars. The composite record (filtered to include only those fires that scarred at least $25 \%$ of recording trees in all three sites) is shown with years below the chart. Software used was FHX2 version 3.2 (Grissino-Mayer 2001). Also shown is a running (10-year) average of the number of fires per decade (bottom panel).

from 1589 to 1892 with no pulse of regeneration evident at any time in either site.

Between 1774 and 1929, out of 38 years with fires, seven years $(18 \%)$ had fires recorded at all three sites (SO, DI, and MA): 1786, 1819, 1831, 1838, 1899, 1909, and 1920 . Twenty-two fire dates $(58 \%)$ were unique to one site only and nine fire dates $(24 \%)$ were recorded at two sites. Although the sites did not share many of the same fire years, all three sites recorded similar numbers of fires during the period 1774-1929 (21 fires in SO, 23 fires in DI, and 17 fires in MA).

We were able to determine seasonality of $55 \%$ of the fire scars. Of those, $92 \%$ were found on the ring boundary, meaning that the majority of fires occurred in the dormant season (Table 1). Another 5\% were found in early earlywood, and 3\% were found in middle earlywood. No scars were found in the late earlywood or latewood.

A dramatic decline in fire frequency occurred after the 1920s (Fig. 2). Site SO experienced one fire between 1920 and 1998 (1955), DI had no fires between 1929 and 1998, and MA had one fire between 1929 and 1995 (1951). Site SO had a 43-year fire-free interval, DI had a 69-year firefree interval, and MA had a 44-year fire-free interval. The fire-free periods in the 20th century were unprecedented in the previous 300+ years: previously, the longest intervals without fire in each of the sites were 19, 32, and 16 years, respectively.

Peña Nevada showed no evidence of a hiatus in fire occurrence that would coincide with the gap in fire in the late 18th and early 19th centuries documented at many sites in the southwestern United States and northwestern Mexico. We did, however, observe a period of few fires from the 1680s to 1717, and another period of few fires from the 1750 s to 1774 , as reflected in reduced fires per decade (Fig. 2).

\section{Fire-climate}

ENSO events were related to fire occurrence in the early portion of our period of analysis, but the relationship changed over time. Results from the SEA analyses indicate that in the period 1645-1831 fires were 
Table 1. Fire interval characteristics at three sites on Peña Nevada in the Sierra Madre Oriental, Mexico.

\begin{tabular}{|c|c|c|c|c|}
\hline \multirow[b]{2}{*}{ Characteristics } & \multicolumn{4}{|c|}{ Site, years of analysis } \\
\hline & $\begin{array}{c}\text { San Onofre (SO) } \\
1641-1920\end{array}$ & $\begin{array}{c}\text { El Diferencial (DI) } \\
1645-1929\end{array}$ & $\begin{array}{c}\text { Mesa Acuña (MA) } \\
1774-1928\end{array}$ & $\begin{array}{c}\text { Three sites combined } \\
1645-1929\end{array}$ \\
\hline Total fires & 113 & 188 & 103 & 408 \\
\hline Number (proportion) with season & $72(0.64)$ & $108(0.57)$ & $42(0.41)$ & $224(0.55)$ \\
\hline Number (proportion) DE fires & $70(0.97)$ & $106(0.98)$ & $39(0.93)$ & $217(0.97)$ \\
\hline \multicolumn{5}{|l|}{ Total no. intervals } \\
\hline All fires & 30 & 33 & 16 & 53 \\
\hline $25 \%$ scarred & 15 & 21 & 13 & 19 \\
\hline \multicolumn{5}{|l|}{ Mean fire interval (yr) } \\
\hline All fires & 9.3 & 8.6 & 9.6 & 5.4 \\
\hline $25 \%$ scarred & 18.6 & 13.5 & 11.9 & 14.5 \\
\hline \multicolumn{5}{|l|}{ Median fire interval (yr) } \\
\hline All fires & 7.5 & 8 & 10 & 5 \\
\hline $25 \%$ scarred & 13 & 12 & 11 & 12 \\
\hline \multicolumn{5}{|l|}{ Weibull median interval (yr) } \\
\hline All fires & 7.9 & 8.1 & 9.6 & 4.6 \\
\hline $25 \%$ scarred & 18.1 & 13.0 & 11.6 & 13.6 \\
\hline \multicolumn{5}{|l|}{ Weibull modal interval (yr) } \\
\hline All fires & 4.1 & 6.8 & 9.7 & 2.6 \\
\hline $25 \%$ scarred & 16.7 & 11.7 & 11.0 & 11.7 \\
\hline \multicolumn{5}{|l|}{ Minimum interval (yr) } \\
\hline All fires & 1 & 1 & 3 & 1 \\
\hline $25 \%$ scarred & 10 & 6 & 6 & 1 \\
\hline \multicolumn{5}{|l|}{ Maximum interval (yr) } \\
\hline All fires & 32 & 19 & 16 & 19 \\
\hline $25 \%$ scarred & 33 & 32 & 23 & 32 \\
\hline
\end{tabular}

Note: The Weibull distribution provides a standard way to compare fire regimes across ecological gradients (Grissino-Mayer 1999). Number with season means the number of fire scars for which an intra-ring position could be determined. DE fires are those that occur during the dormant period or when the tree is putting on its first earlywood (early earlywood).

likely to occur in La Niña years (years when NINO3 values were significantly below average; Fig. 3). This relationship was significant $(P<0.05)$ for fires that scarred $\geq 25 \%$ of recording trees. Between 1832 and 1929, however, there is no significant relationship between ENSO and years when fires burned, regardless of the size of the fire. For fires that scarred $\geq 25 \%$ of recording trees before 1831 , the $3-5$ years before fire years had significantly above-average NINO3 values. After 1832, the year immediately prior to widespread fires (those that scarred $\geq 25 \%$ of recording trees) had significantly above-average NINO3 values.

The decoupling of La Niña and dry, fire-prone years in the early 19th century was further explored with additional analyses. First, SEA analyses associating extreme ENSO events and precipitation show that before 1830, extreme La Niña events (Stahle and Cleaveland 1993) were likely to be very dry $(P<$ 0.01), but approximately average after 1832 (Fig. 3). Second, by overlaying SOI extremes on a graph of reconstructed Peña Nevada winter precipitation (Fig. 4), it is evident that from 1700 to 1830 , four of the five El Niño extremes corresponded with precipitation maxima and six of the seven La Niña extremes coincided with precipitation minima (Fig. 4). Between the 1830s and the 1970s, the extremes were less distinguishable in the Peña Nevada precipitation record; El Niño extremes still tended to be wet but La Niña extremes ranged from dry to wet conditions. In the late 20 th century, it appears the patterns of precipitation during extreme ENSO events have diverged even more dramatically. The El Niño events of 1983 and 1998 were extremely dry years at Peña Nevada; 1998 was the second-driest year at Peña Nevada since 1508 in a precipitation reconstruction using $P$. menziesii annual rings (Villanueva-Diaz et al. 2007). Since 1508 , only 1805 , which was an extreme La Niña year, was drier.

Regardless of ENSO phases, fires occurred more often in dry years at Peña Nevada throughout the period of analysis (Fig. 3). Only the "all fires" relationship between fire years and precipitation before 1831 did not reach $95 \%$ significance. The other categories of fire both before 1831 and after 1832 were significantly related to years of low precipitation. The seven years when fires occurred in all three sites were significantly dry, and there was also, on average, a significantly wet year two years prior to these seven fire years (not shown).

\section{Discussion}

What were the characteristics of the fire regime?

Before the 1920s, the fire regime at Peña Nevada was characterized by relatively frequent surface fires, as 
$1645-1831$

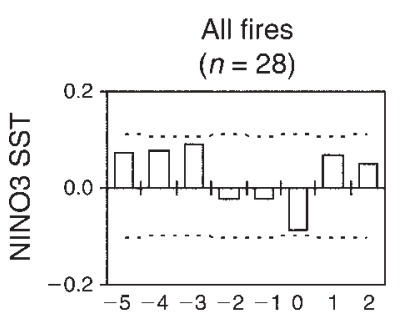

Fires with $\geq 25 \%$ scarred $(n=13)$
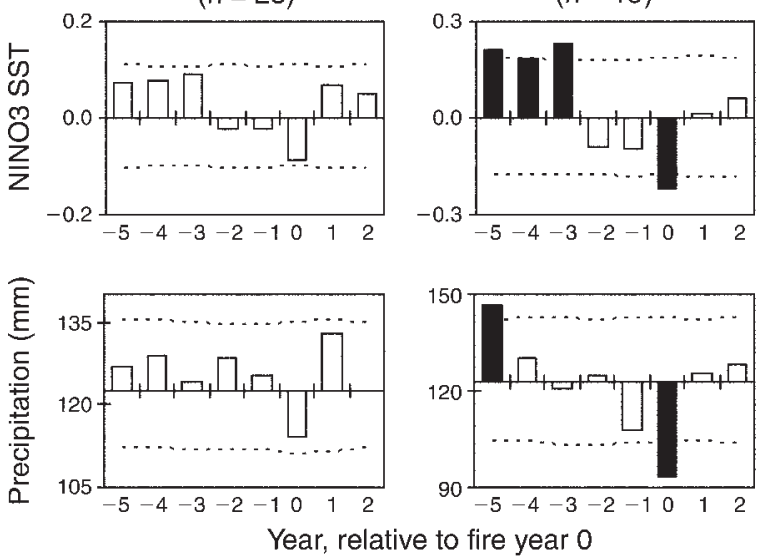

Extreme La Niña

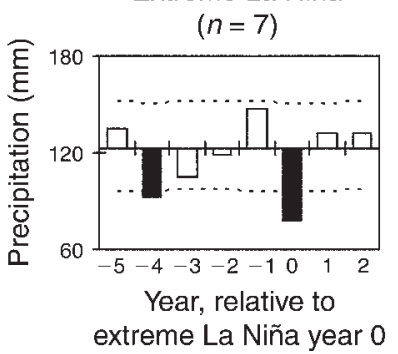

$1832-1929$

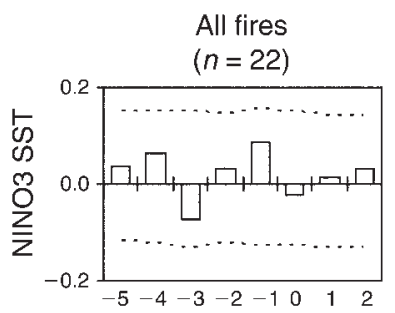

Fires with $\geq 25 \%$ scarred $(n=7)$
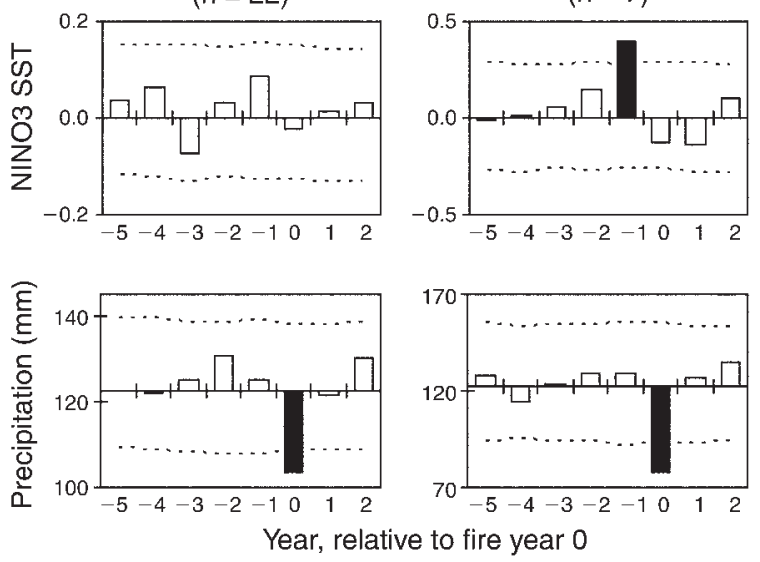

Extreme La Niña

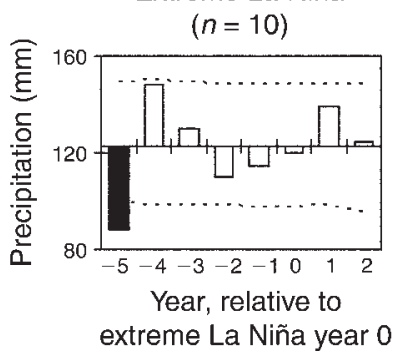

FIG. 3. Superposed epoch analysis before 1831 and after 1832 showing departure from the mean value of NINO3 SST (top; sea surface temperatures; Cook 2000) and precipitation (middle; local reconstruction; Villanueva et al. 2007) for all fire years and fire years in which $\geq 25 \%$ of samples were scarred. Fire years are indicated by 0 , and values are also given for five years prior to fire years (negative values) and 2 years after fire years. Black bars are those that pass the $95 \%$ confidence interval. Bottom: superposed epoch analysis showing departure from the mean value of precipitation for extreme La Niña years before 1831 and after 1832 . La Niña years are indicated by 0 . NINO3 is a unitless index.

indicated by our reconstruction reaching back several hundred years. Individual trees were scarred by fire up to 10 times each; on average, individual trees were experiencing and surviving fires more frequently than every two decades throughout their lives (individual tree mean fire interval 17 years). This is a conservative estimate, as not all fires leave scars on recording trees, and we excluded fires with uncertain dates from all statistical analyses. The historical fire regime at Peña Nevada is similar to the historical low-severity surface fire regime found in the more northerly dry coniferous forests of northwestern Mexico and the southwestern United States (Fulé and Covington 1999, Heyerdahl and Alvarado 2003, Stephens et al. 2003, Fulé et al. 2005). This is true even though the dominant species at Peña Nevada ( $P$. hartwegii) is different from any species sampled in other fire history studies, and these sites are at a much higher elevation.

Unlike some high elevation sites in the western United States (Kipfmueller and Baker 2000, Margolis et al. 2007), we did not find evidence of stand-replacing fires from the 1500s through the early 1900s, although there is a possibility that site MA experienced a stand- replacing fire in the early 1700 s based on the lack of sample coverage before 1725 and the pulse of regeneration between 1726 and 1742. In addition, although we found old, fire-scarred trees dating back centuries in our other sites, meaning that no stand-replacing fire at the 25-ha scale had occurred since at least $\sim 1600$, it is possible that smaller patches within our sites experienced high-severity fire that we did not detect. We conclude that the historical fire regime was dominated by low-severity surface fires, with the possibility of patchy stand-replacing disturbances in some sites.

A stand-replacing fire did occur in 1998 in all three sites after decades of fire exclusion, and there is evidence that a severe, stand-replacing fire occurred in 1983 on a different part of the mountain. There are two possible explanations for the seemingly anomalous severity of these fires in the late 20th century. One is that decades of fire exclusion led to a buildup of fuels, which facilitated the crown fires in the extremely dry years of 1983 and 1998. The other possible scenario is that our three ridgetop sites captured evidence of predominantly surface fires. We leave open the possibility that the larger Peña Nevada landscape historically experienced 


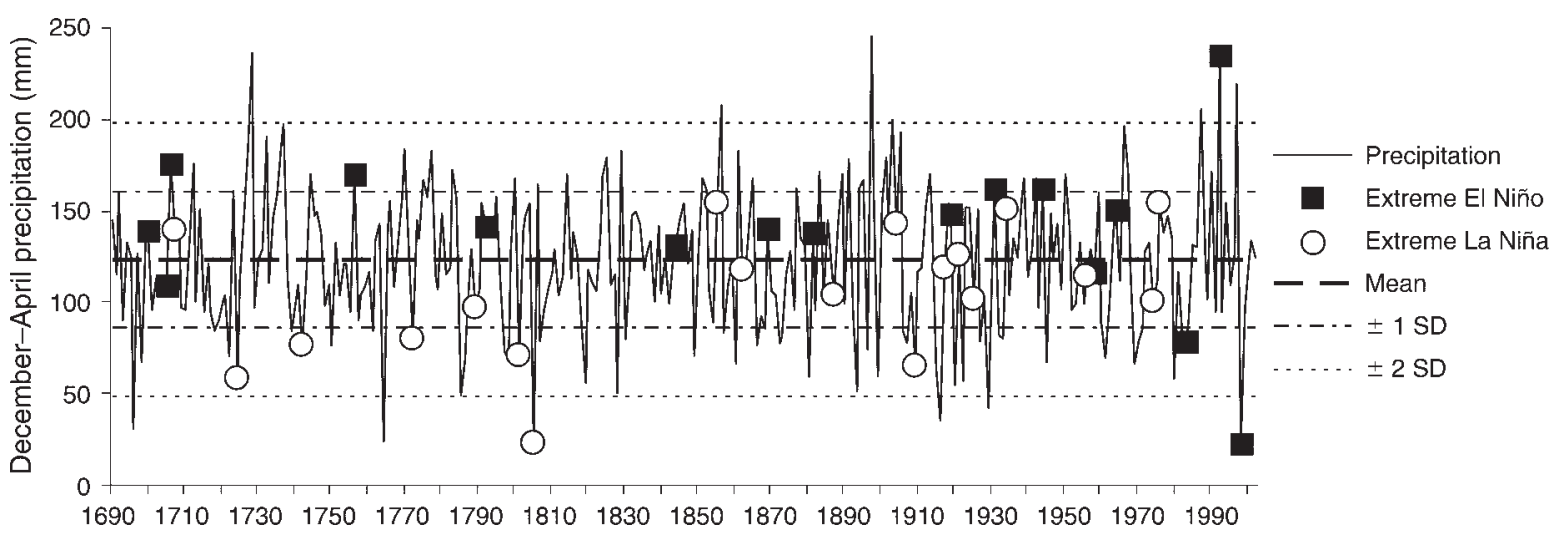

FIG. 4. Relationship between reconstructed precipitation at Peña Nevada and extreme El Niño and La Niña years (extreme years 1699-1971 from Stahle and Cleaveland [1993]).

some severe fires as well as surface fires and that the late 20 th century severe fires were not as unusual as the evidence suggests.

More than half the fires during the period of analysis were small and burned in only one of the three sites sampled. Surprisingly, since the three sites are within a $3-\mathrm{km}$ section of the ridgetop, fires were not generally synchronous between the three sites. Only seven fire dates between 1774 and 1929 were recorded at all three sites. These results suggest that fires in our sites were frequent but not usually very large. Frequent but small and asynchronous fires have also been found in western Mexico, in the Sierra Madre Occidental (Fulé and Covington 1999), although in other areas of the Sierra Madre Occidental fires were historically more large and synchronous (Fulé et al. 2005).

An unusual feature of the Peña Nevada fire history is the almost complete dominance of dormant-season fires (206 of 224 fires; 92\%); almost all of the fires recorded occurred before cambial growth began. Although little is known about growth phenology in this region, the dominance of scars on the ring boundary or in the early earlywood suggests that the majority of scars were formed in the spring or early summer. These seasonality results, including the lack of scars in the latewood, support the assumption that dormant-season fires occur in the spring rather than in the fall. We hypothesize that the high percentage of dormant-season scars at Peña Nevada is due to the high elevation. Cambial growth of trees likely begins relatively late in the year, while most lightning strikes in this area occur during the spring before the first precipitation peak in May (IMTA 2007). In sites studied in western Mexico, percentage of dormant-season fires ranged from $0.3 \%$ (Skinner et al. 2008 ) to $47 \%$ (Fulé et al. 2005) to $56 \%$ (Fulé and Covington 1999) to $63 \%$ (Heyerdahl and Alvarado 2003).

This is the first study to quantify fire history from fire scars in a $P$. hartwegii forest. This species is capable of basal resprouting, which has been interpreted in other tree species as an adaptation to stand-replacing disturbance, including crown fire (Rodríguez-Trejo and Fulé 2003). However, we did not see any $P$. hartwegii sprouts at Peña Nevada, and our data indicate that in our sites, the $P$. hartwegii forest sustained a surface fire regime for the past several hundred years.

\section{Was the fire regime interrupted in the 20th century?}

The near cessation of fires after the 1920s is likely related to the formation of Ejido La Encantada on Peña Nevada in 1937. Ejidos are communities that live on rural lands that are held in common and managed with some level of governmental control (Thoms and Betters 1998). In the Sierra Madre Occidental, a decrease in the percentage of sites with fire around 1930 coincided with the granting of lands to ejidos (Heyerdahl and Alvarado 2003). Heyerdahl and Alvarado speculated that granting land to ejidos may have changed the fire regime through the introduction or intensification of cattle grazing, road building, logging, and changing the traditional role of fire. These same factors likely changed the fire regime at Peña Nevada when Ejido La Encantada was formed. Other hypotheses are less likely; there is no evidence of a climatic change in this area in the early 1900s (Villanueva-Diaz et al. 2007), and throughout Mexico fire regimes were disrupted during different decades (i.e., the 1930s and 1940s [Fulé and Covington 1999] and the 1950s [Fulé et al. 2005]) or not at all. This suggests that climate is not responsible for the cessation of fires after the 1920s at Peña Nevada. Fire suppression policy is probably not the reason for the cessation of fires either: control efforts in this area have been limited in scope (local crews and landowners, rather than engines and helicopters).

We have no data on human population history or the history of fire use at Peña Nevada, and we cannot distinguish human ignitions from lightning ignitions throughout the period of record. The many small fires on the peak indicate many local ignitions, meaning that fires did not always start in the centers of population in 
the valleys below. Given the elevation of the mountain, lightning strikes probably occur often. Lightning in this area peaks before the early summer rains begin, which is consistent with the fact that almost all fires with determinable season occurred in spring or early summer before cambial growth began. However, humans may also have ignited fires in these high-elevation forests, and it is most likely that both lightning and humans caused fires historically.

\section{What are the effects of ENSO and other climate patterns on fires in this region of Mexico?}

As expected, fires tended to burn at Peña Nevada during dry years. This pattern did not change throughout the period of record. For most categories of fire, we saw no evidence that fires were related to high precipitation in years preceding fires, as has been found in many sites in the southwestern United States (e.g., Grissino-Mayer et al. 2004). However, the seven years in which fires burned all three sites show evidence of occurring two years after a wet year, which could indicate that the most widespread fires were influenced by the buildup of fine fuels during wet years.

The most striking characteristic of the relationship between ENSO, dry years, and fire at Peña Nevada is the shifting relationship between El Niño/La Niña, precipitation, and fire over time, with one shift occurring around 1830 and another occurring in the last few decades (around 1970). Before the 1830s, La Niña had a significant effect on the occurrence of fire at Peña Nevada: negative NINO3 values were strongly associated with fire years (Fig. 3). This is consistent with studies in northwestern Mexico and the southwestern United States (Swetnam and Betancourt 1998, Heyerdahl and Alvarado 2003, Kitzberger et al. 2007, Drury and Veblen 2008). After 1830, the relationship between fire and La Niña at Peña Nevada was not significant. Fires continued to burn in dry years, but they were no longer associated with La Niña (Fig. 3). Since the 1970s, extreme ENSO events have been more erratic; the extreme El Niño events of 1983 and 1998 were very dry at Peña Nevada but the 1992 extreme El Niño was very wet (Fig. 4).

While numerous studies have associated ENSO patterns with fire occurrence in the Americas, to our knowledge this is the first study to document a change in the effects of ENSO on the occurrence of fire over time. The reason for the change is not clear. We hypothesize that the changing nature of the ENSO-fire relationship could be due to (1) the location of this study site, (2) climatic shifts associated with the late 18th-early 19th century gap in fire, or (3) possible effects from climate change. Peña Nevada is located in the transition zone, or dipole, of ENSO effects: northwestern Mexico tends to be dry during La Niña events while southern Mexico tends to be dry during El Niño events (Magaña et al. 2003). Because this is the first fire-climate study in this part of North America, we do not know if this result is anomalous or typical. Tree-ring chronologies and precipitation reconstructions from elsewhere in the Sierra Madre Oriental show that 1998 was anomalously dry in other places in northeastern Mexico. This is also evident in maps of extreme El Niño events created by Magaña et al. (2003). The dryness in an El Niño winter normally extends up partway through Mexico, but in 1998 the drying extended much farther north, including our study area. We will explore further whether geographic location in relation to spatial teleconnections is responsible for the shifting effects of ENSO on precipitation and fire as we analyze data from other fireclimate studies in this region, currently underway.

Although we saw no evidence of a hiatus in fire at Peña Nevada coincident with the late 18th-early 19th century gap in fire, as has been recorded at many other sites in North and South America, the first shift in ENSO effects at this site occurred around 1830, which is approximately when changes in fire regime, or in some cases the end of the hiatus, happened in several other areas. For example, Stephens et al. (2003) noted less frequent and more synchronous fires after $\sim 1830$ in the Sierra San Pedro Mártir in northern Baja California. Sakulich and Taylor (2007) also documented a shift from frequent small burns to less frequent larger burns after 1800 in their study area in western Texas. The reasons and the precise dates for the shift in fire regime, or in some cases "the gap," are still unresolved. Hypotheses include decreased amplitude and/or frequency of ENSO, a cool phase of the Atlantic multidecadal oscillation (AMO), a cool phase of the Pacific decadal oscillation (PDO), and lower variability in climate in general (Donnegan et al. 2001, Kitzberger et al. 2001, 2007, Heyerdahl et al. 2002, Grissino-Mayer et al. 2004, Brown and Wu 2005, Sibold and Veblen 2006, Brown et al. 2008, Skinner et al. 2008). It is possible that at Peña Nevada one or more of these hypotheses could explain the change in ENSO effects in $\sim 1830$ and the change after the 1970s as well.

The change in ENSO effects at Peña Nevada in the late 20th century (around 1970) is more dramatic than the early 1800s change. After centuries of receiving above-average precipitation during El Niño events, Peña Nevada experienced the second-driest year in almost 500 years during the El Niño event of 1998 (Villanueva-Diaz et al. 2007). The year 1983, when another El Niño event occurred, was also dry at Peña Nevada according to the local tree-ring record. Some scientists attribute the unprecedented amplitudes of the 1983 and 1998 El Niño events to anthropogenically induced global climate changes, while others do not (Fedorov and Philander 2000). Climate change is likely to affect El Niño by altering the background climate, but of the several projections that have been made about details of these changes, it is currently impossible to know which, if any, are correct (Fedorov and Philander 2000, Tudhope and Collins 2003). 


\section{Were the fires in the 1998 El Niño an anomaly?}

At our sites on Peña Nevada, we have evidence of both top-down and bottom-up control of fires, including the anomalously severe fire of 1998. The severity of this fire was probably due in large part to top-down influences of climate: low precipitation and high temperatures. In 1998, Peña Nevada received very little precipitation. The year 1998 was also the warmest year of the 20th century (McPhaden 1999), which may have influenced the area burned globally that year, as well as area burned in Mexico and the Sierra Madre Oriental. Unusually severe wildfires like the one that burned Peña Nevada in 1998 will probably occur again if projections of warming and drying are realized (Westerling et al. 2006, Seager et al. 2007, 2009).

Changes in the bottom-up influences of fuels and forest structure also may have had an impact on the large size and severity of the El Niño fire of 1998. The forests in our sites, adapted to fairly frequent surface fire, had not experienced wildfires for more than 40 (and in some cases almost 70) years before 1998. The resulting buildup of fuels and changes in canopy structure over time may have contributed to the severe impacts that occurred when a fire finally did burn during a dry year.

The low-intensity surface fires that historically burned in our sites were also likely influenced by both top-down and bottom-up effects. Evidence for bottom-up control is the dominance of small asynchronous fires that occurred at only one of the three sites from 1645 to 1929, suggesting that differences in fuels, ignitions, and site characteristics were important at this small scale.

Top-down influence on the historical low-intensity surface fires is evidenced by the strong relationship of fire with dry years, throughout the period of record. In addition, before the 1830s, ENSO also had a strong relationship with fire occurrence. Prior to the 1920s, when fire exclusion began, bottom-up controls like fuel availability probably moderated top-down climatic influences. However, the bottom-up control that fuel exerted was eliminated when fire exclusion began and fuels became more homogeneous and probably more dense. This may have allowed top-down extreme climatic controls to dominate fire behavior in the late 20th century.

The dominant trees at Peña Nevada survived multiple fires over centuries, but an event of mass mortality occurred in our study area in 1998, probably due to a combination of fuel buildup and extreme dryness. Considering possible changes in future climate and the biological importance of the Sierra Madre Oriental, including the high number of local endemics, this merits concern and the development of new strategies for conservation. In some parts of Mexico, excessive human-originated fire has contributed to deforestation or forest structure changes in pine forests. Public education campaigns have been implemented throughout the country to reduce excessive burning (RodríguezTrejo and Fulé 2003). However, in the Sierra Madre
Occidental in northwestern Mexico, there are areas where fire frequency today is similar to historical fire frequency and areas where fires, historically frequent, have been absent or rare for decades (Rodríguez-Trejo and Fulé 2003). Based on our reconstruction of fire history at Peña Nevada, fires occurred much less frequently after the 1920s than in the previous several centuries. Fire suppression in areas with fire regimes historically characterized by frequent surface fires is not the best management tool, as it may contribute to forest change, fuel buildup, and increased risk of catastrophic crown fires. It is useful to understand the historical fire regimes of these forests to design the best management approaches for these areas. In addition, understanding how ENSO and other climate factors influence precipitation and fire is important; ENSO may no longer be a reliable indicator of precipitation or fire occurrence or behavior in this part of Mexico. It will be valuable to expand the network of fire-climate sites to enhance our understanding of fire-climate relationships and to further investigate whether ENSO effects on precipitation and fire are changing throughout the region or whether it is a site-specific phenomenon.

\section{ACKNOWLEDGMENTS}

We thank Ejido La Encantada and Davíd Medellín for permission to work on Peña Nevada. Gustavo Medellín Pérez provided invaluable assistance in the field, as did Armando Becvort, Erica Bigio, Vicenta Constante García, and Cameron Fulé. Many thanks also to Don Normandin, Ian Hyp, Joe Crouse, and other staff at the Ecological Restoration Institute. This research was supported by the National Science Foundation (DEB-0640351) and the Ecological Restoration Institute at Northern Arizona University. We also thank Emily Heyerdahl and one anonymous reviewer for their helpful comments on the manuscript.

\section{Literature Cited}

Baisan, C. H., and T. W. Swetnam. 1990. Fire history on a desert mountain range: Rincon Mountain Wilderness, Arizona, USA. Canadian Journal of Forest Research 20: $1559-1569$

Brown, P. M., E. K. Heyerdahl, S. G. Kitchen, and M. H. Weber. 2008. Climate effects on historical fires (1630-1900) in Utah. International Journal of Wildland Fire 17:28-39.

Brown, P. M., and $\mathrm{R}$. Wu. 2005. Climate and disturbance forcing of episodic tree recruitment in a southwestern ponderosa pine landscape. Ecology 86:3030-3038.

Caso, M., C. González-Abraham, and E. Ezcurra. 2007. Divergent ecological effects of oceanographic anomalies on terrestrial ecosystems of the Mexican Pacific coast. Proceedings of the National Academy of Sciences USA 104:10530 10535.

Cook, E. R. 2000. Nino 3 index reconstruction. International Tree-Ring Data Bank. IGBP PAGES/World Data Center-A for Paleoclimatology Data Contribution Series Number 2000-052. NOAA/NGDC Paleoclimatology Program, Boulder, Colorado, USA.

Donnegan, J., T. T. Veblen, and J. S. Sibold. 2001. Climatic and human influences on fire history in Pike National Forest, central Colorado. Canadian Journal of Forest Research 31: 1526-1539.

Drury, S. A., and T. T. Veblen. 2008. Spatial and temporal variability in fire occurrence within the Las Bayas Forestry Reserve, Durango, Mexico. Plant Ecology 197:299-316. 
Duncan, B. N., R. V. Martin, A. C. Staudt, R. Yevich, and J. A. Logan. 2003. Interannual and seasonal variability of biomass burning emissions constrained by satellite observations. Journal of Geophysical Research 108(D2) 4100.

Farjon, A., and B. T. Styles. 1997. Pinus (Pinaceae). New York Botanical Garden, Bronx, New York, USA.

Fedorov, A. V., and S. G. Philander. 2000. Is El Niño changing? Science 288:1997-2002.

Ferrusquía-Villafranca, I. 1993. Geology of Mexico: a synopsis. Pages 3-108 in T. P. Ramamoorthy, R. Bye, A. Lot, and J. $\mathrm{Fa}$, editors. Biological diversity of Mexico: origins and distribution. Oxford University Press, New York, New York, USA.

Fulé, P. Z., and W. W. Covington. 1994. Fire-regime disruption and pine-oak forest structure in the Sierra Madre Occidental, Durango, Mexico. Restoration Ecology 2:261-272.

Fulé, P. Z., and W. W. Covington. 1999. Fire regime changes in La Michilía Biosphere Reserve, Durango, Mexico. Conservation Biology 13:640-652.

Fulé, P. Z., J. Villanueva-Díaz, and M. Ramos-Gómez. 2005. Fire regime in a conservation reserve in Chihuahua, Mexico. Canadian Journal of Forest Research 35:320-330.

González Tagle, M. A., L. Schwendenmann, J. Jiménez Pérez, and W. Himmelsbach. 2007. Reconstrucción del historial de incendios y estructura forestal en bosques mixtos de pinoencino en la Sierra Madre Oriental. Madera y Bosques 13: $51-63$.

Grissino-Mayer, H. D. 1999. Modeling fire interval data from the American Southwest with the Weibull distribution. International Journal of Wildland Fire 9:37-50.

Grissino-Mayer, H. D. 2001. FHX2 - software for analyzing temporal and spatial patterns in fire regimes from tree rings. Tree-Ring Research 57:113-122.

Grissino-Mayer, H. D., W. H. Romme, M. L. Floyd, and D. D. Hanna. 2004. Climatic and human influences on fire regimes of the southern San Juan Mountains, Colorado, USA. Ecology 85:1708-1724.

Heyerdahl, E. K., and E. Alvarado. 2003. Influence of climate and land use on historical surface fires in pine-oak forests, Sierra Madre Occidental, Mexico. Pages 196-217 in T. T. Veblen, W. L. Baker, G. Montenegro, and T. W. Swetnam, editors. Fire and climatic change in temperate ecosystems of the western Americas. Springer-Verlag, New York, New York, USA.

Heyerdahl, E. K., L. B. Brubaker, and J. K. Agee. 2002. Annual and decadal climate forcing of historical fire regimes in the interior Pacific Northwest, USA. Holocene 12:597-604.

Holmes, R. L. 1983. Computer-assisted quality control in treering dating and measurements. Tree-Ring Bulletin 43:69-78.

IMTA. 2007. Extractor Rápido de Información Climatológica, version 3 (ERIC III); compact disc. Instituto Mexicano de Tecnología del Agua, Veracruz, Mexico.

Keeley, J. E., and P. H. Zedler. 1998. Evolution of life histories in Pinus. Pages 219-249 in D. M. Richardson, editor. Ecology and biogeography of Pinus. Cambridge University Press, New York, New York, USA.

Kipfmueller, K. F., and W. L. Baker. 2000. A fire history of a subalpine forest in south-eastern Wyoming, USA. Journal of Biogeography 27:71-85.

Kitzberger, T., P. M. Brown, E. K. Heyerdahl, T. W. Swetnam, and T. T. Veblen. 2007. Contingent Pacific-Atlantic Ocean influence on multicentury wildfire synchrony over western North America. Proceedings of the National Academy of Sciences USA 104:543-548.

Kitzberger, T., T. W. Swetnam, and T. T. Veblen. 2001. Interhemispheric synchrony of forest fires and the El NiñoSouthern Oscillation. Global Ecology and Biogeography 10: 315-326.

Magaña, V. O., J. L. Vásquez, J. L. Pérez, and J. B. Pérez. 2003. Impact of El Niño on precipitation in Mexico. Geofísica Internacional 42:313-330.
Margolis, E. Q., T. W. Swetnam, and C. D. Allen. 2007. A stand-replacing fire history in upper montane forests of the southern Rocky Mountains. Canadian Journal of Forest Research 37:2227-2241.

McDonald, J. A. 1990. The alpine-subalpine flora of northeastern Mexico. Sida 14:21-28.

McDonald, J. A. 1993. Phytogeography and history of the alpine-subalpine flora of northeastern Mexico. Pages 681705 in T. P. Ramamoorthy, R. Bye, A. Lot, and J. Fa, editors. Biological diversity of Mexico: origins and distribution. Oxford University Press, Oxford, UK.

McPhaden, M. J. 1999. Genesis and evolution of the 1997-98 El Niño. Science 283:950-954.

Rodríguez-Trejo, D. A., and P. Z. Fulé. 2003. Fire ecology of Mexican pines and a fire management proposal. International Journal of Wildland Fire 12:23-37.

Rodríguez-Trejo, D. A., and S. J. Pyne. 1999. Mexican fires of 1998. International Forest Fires News 20:61-63.

Román-Cuesta, R. M., J. Retana, and M. Gracia. 2004. Fire trends in tropical Mexico: a case study of Chiapas. Journal of Forestry 102:26-32.

Romme, W. H. 1980. Fire history terminology: report of the ad hoc committee. Pages 135-137 in Proceedings of the Fire History Workshop (20-24 October 1980). USDA Forest Service, Tucson, Arizona, USA.

Sakulich, J., and A. H. Taylor. 2007. Fire regimes and forest structure in a sky island mixed conifer forest, Guadalupe Mountains National Park, Texas, USA. Forest Ecology and Management 241:62-73.

Seager, R., M. Ting, M. Davis, M. Cane, N. Naik, J. Nakamura, C. Li, E. Cook, and D. W. Stahle. 2009. Mexican drought: an observational modeling and tree ring study of variability and climate change. Atmósfera 22:1-31.

Seager, R., et al. 2007. Model projections of an imminent transition to a more arid climate in southwestern North America. Science 316:1181-1184.

Sibold, J. S., and T. T. Veblen. 2006. Relationships of subalpine forest fires in the Colorado Front Range with interannual and multidecadal-scale climatic variation. Journal of Biogeography 33:833-842.

Skinner, C. N., J. H. Burk, M. G. Barbour, E. FrancoVizcaíno, and S. L. Stephens. 2008. Influences of climate on fire regimes in montane forests of north-western Mexico. Journal of Biogeography 35:1436-1451.

Stahle, D. W., and M. K. Cleaveland. 1993. Southern Oscillation extremes reconstructed from tree rings of the Sierra Madre Occidental and southern Great Plains. Journal of Climate 6:129-140.

Stephens, S. L., C. N. Skinner, and S. J. Gill. 2003. Dendrochronology-based fire history of Jeffrey pine-mixed conifer forests in the Sierra San Pedro Martir, Mexico. Canadian Journal of Forest Research 33:1090-1101.

Swetnam, T. W. 1990. Fire history and climate in the southwestern United States. Pages 6-17 in Proceedings of the Symposium "Effects of fire management of southwestern natural resources." USDA Forest Service General Technical Report RM-191, Tucson, Arizona, USA.

Swetnam, T. W. 1993. Fire history and climate change in giant sequoia groves. Science 262:885-889.

Swetnam, T. W., and J. L. Betancourt. 1990. Fire-Southern Oscillation relations in the southwestern United States. Science 249:1017-1020.

Swetnam, T. W., and J. L. Betancourt. 1998. Mesoscale disturbance and ecological response to decadal climatic variability in the American Southwest. Journal of Climate 11:3128-3147.

Thoms, C. A., and D. R. Betters. 1998. The potential for ecosystem management in Mexico's forest ejidos. Forest Ecology and Management 103:149-157.

Tudhope, S., and M. Collins. 2003. The past and future of El Niño. Nature 424:261-262. 
Van Horne, M. L., and P. Z. Fulé. 2006. Comparing methods of reconstructing fire history using fire scars in a southwestern United States ponderosa pine forest. Canadian Journal of Forest Research 36:855-867.

Villanueva-Diaz, J., D. W. Stahle, B. H. Luckman, J. CeranoParedes, M. D. Therrell, M. K. Cleaveland, and E. Cornejo-
Oviedo. 2007. Winter-spring precipitation reconstructions from tree rings for northeast Mexico. Climatic Change 83: $117-131$.

Westerling, A. L., H. G. Hidalgo, D. R. Cayan, and T. W. Swetnam. 2006. Warming and earlier spring increase western U.S. forest wildfire activity. Science 313:940-943. 